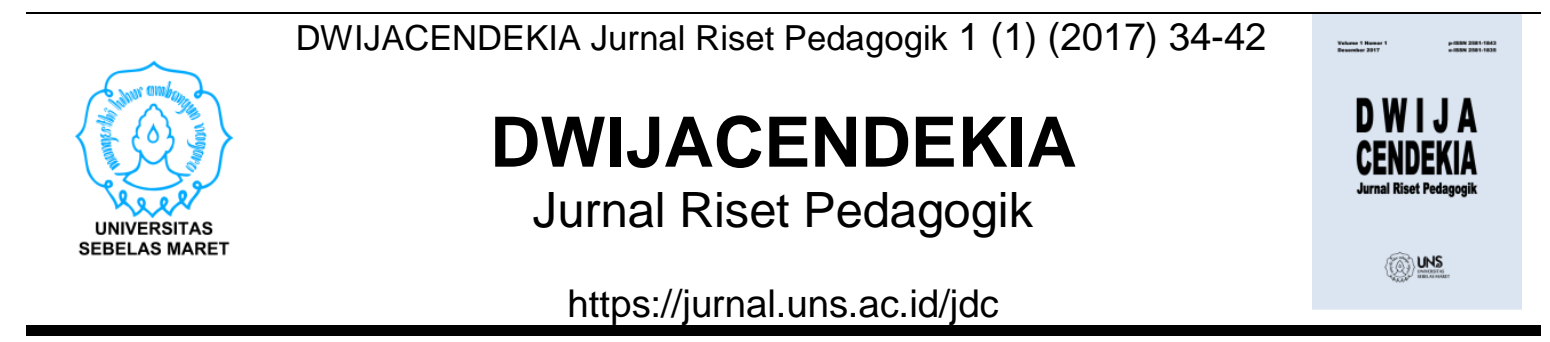

\title{
PENGARUH MODEL PEMBELAJARAN KOOPERATIF VS PRESENTASI DISKUSI TERHADAP PEMAHAMAN KONSEP (KEEFEKTIFAN DAN DAYA TARIK PEMBELAJARAN) MAHASISWA PADA MATAKULIAH PENDIDIKAN IPS DI JURUSAN PGSD FKIP UNIKU
}

\section{Eli Hermawati}

Universitas Kuningan

\section{Sejarah Artikel}

Diterima 15 Juli 2017

Disetujui 21 Juli 2017

Diterbitkan 1 Agutus 2017

\section{Kata Kunci}

pemahaman konsep, pembelajaran kooperatif, presentasi diskusi

\begin{abstract}
Abstrak
Penelitian ini dilatarbelakangi oleh matakuliah konsep dasar IPS semester satu yang menerapkan presentasi diskusi tetapi kurang mendapat respon positif dari mahasiswa, terlebih untuk mahasiswa semester satu yang masih perlu banyak pemahaman konsep dasar. Dimulai dari belum bisa mengemukakan pendapatnya secara lugas, tidak percaya diri, dan merasa jenuh. Oleh karena itu peneliti merubah gaya mengajar menggunakan pembelajaran kooperatif. Penelitian ini bertujuan untuk mengetahui perbedaan pemahaman konsep mahasiswa antara penggunaan model pembelajaran kooperatif dengan presentasi diskusi. Penelitian ini dilaksanakan di Jurusan PGSD FKIP UNIKU pada matakuliah Pendidikan IPS SD dengan sample penelitian semester 2 Kelas B dan C. Penelitian ini merupakan eksperimen kuasi dengan pendekatan kuantitatif. Instrumen penelitian berupa tes dan angket. Hasil penelitian menunjukan bahwa terdapat perbedaan pemahaman konsep mahasiswa antara penggunaan model pembelajaran kooperatif dengan metode presentasi diskusi. Hal ini terlihat dari Uji Mann-Whitney pemahaman konsep mahasiswa dengan menggunakan pembelajaran kooperatif mengalami peningkatan lebih tinggi daripada dengan menggunakan presentasi diskusi. Berdasarkan hasil penelitian ini, penulis menyarankan kepada para dosen penggunaan pembelajaran kooperatif dapat menjadi sumber rujukan dalam memilih pendekatan pembelajaran dalam memberi perkuliahan kepada mahasiswa.
\end{abstract}

\section{Cara Mengutip}

Hermawati, E. (2017). Pengaruh Model Pembelajaran Kooperatif vs Presentasi Diskusi Terhadap Pemahaman Konsep Mahasiswa pada Mata Kuliah Pendidikan IPS si Jurusan PGSD FKIP UNIKU. DWIJACENDEKIA Jurnal Riset Pedagogik, 1(1), 34-42.

Korespondensi Penulis: elihermawati08@gmail.com 


\section{PENDAHULUAN}

Proses pembelajaran yang telah banyak dilakukan di PGSD UNIKU yaitu dengan penggunaan metode presentasi diskusi kelompok di kelas, hampir setiap dosen menerapkan metode tersebut dan penelitipun menerapkan hal yang sama. Tetapi setelah diamati ternyata penggunaan metode ini ada kelemahmannya yaitu mahasiswa tidak terlibat semua, yang aktif hanya sekelompok mahasiswa saja bahkan untuk penguasaan materi mereka hanya memahami materi dari topik yang mereka kerjakan sedangkan untuk topik-topik yang lainnya mereka kurang paham.

Penelitian ini berangkat dari respon mahasiswa dalam pembelajaran dengan menggunakan metode presentasi diskusi kelompok mereka sudah merasa jenuh dan bosan karena hampir setiap matakuliah menggunkan metode yang sama. Disamping itu mahasiswa tidak memahami konsep yang dipresentasikan temannya dikelas. Hal ini mungkin karena tidak semua siswa terlibat aktif dalam pembelajaran.

Dari pengalaman peneliti mengajar mata kuliah konsep dasar IPS metode presentasi diskusi kurang mendapat respon positif dari mahasiswa, terlebih untuk mahasiswa semester satu yang masih perlu banyak pemahaman konsep dasar. Dimulai dari mereka belum bisa mengemukakan pendapatnya secara lugas, tidak percaya diri, metode presentasi juga dinilai membuat siswa jenuh. Hal ini terlihat dari hasil belajar mereka, untuk mata kuliah konsep dasar IPS banyak siswa nilai UTS dan UAS nya dibawah 70 . Hal ini membuat peneliti berinisiatif untuk merubah gaya mengajar yang dilakukan. Dalam hal ini merubah metode pembelajaran dengan menggunakan pembelajaran kooperatif.

Model cooperative learning, adalah strategi belajar mengajar dengan jalan mengelompokkan mahasiswa berdasarkan tingkat kemampuannya pada kelompok yang kecil. Pada cooperative learning, keberhasilan peserta didik akan tercapai jika dan hanya jika setiap anggota kelompoknya berhasil (Deutsch, 1962). Menurut Slavin (1995), pengaruh kerja kelompok secara umum adalah positif. Pada bukti terbaiknya Slavin menemukan bahwa $72 \%$ dari 68 studi menunjukkan prestasi yang tinggi untuk kerja kelompok (cooperative learning) pada kelompok eksperimen dibandingkan kelas kontrol. Penelitian ini ingin mengetahui sejauhmana metode presentasi diskusi kelas yang selama ini digunakan dalam pembelajaran di PGSD UNIKU efektif dalam proses belajar mengajar dengan membandingkannya dengan model pembelajaran kooperatif.

Berdasarkan pemaparan diatas mengenai metode presentasi diskusi kelas dan model pembelajaran kooperatif maka penelitian ini akan membandingkan pengaruh model pembelajaran kooperatif dan presentasi diskusi terhadap pemahaman konsep mahasiswa pada matakuliah Pendidikan IPS di Jurusan PGSD FKIP UNIKU. 


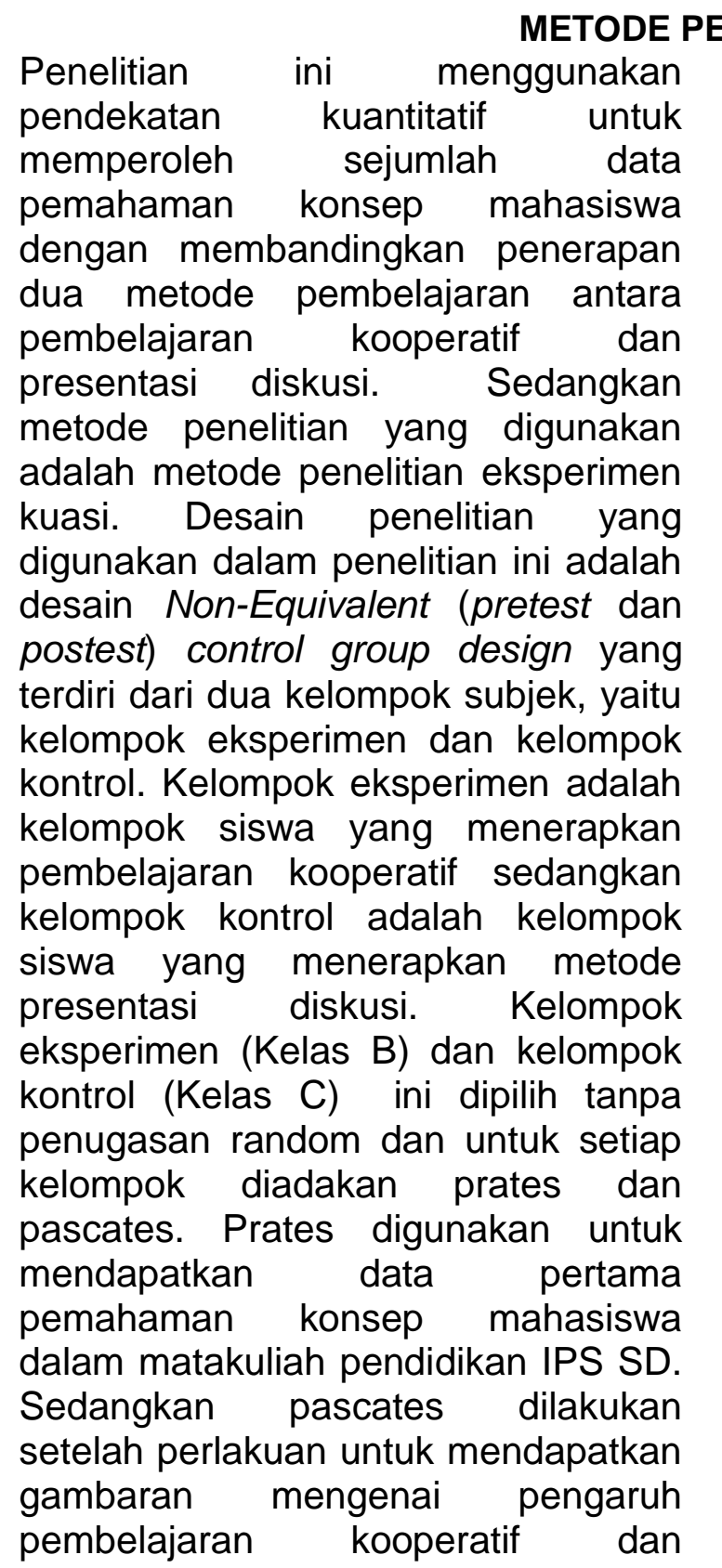

presentasi

diskusi

terhadap

pemahaman konsep mahasiswa

dalam matakuliah pendidikan IPS SD.

Penelitian dilaksanakan di Prodi

PGSD FKIP Universitas Kuningan.

Adapun yang menjadi subjek

penelitian ini adalah mahasiswa

tingkat 1 semester 2 sebanyak 70

mahasiswa. Dengan perincian kelas B

sebanyak 35 sebagai kelas

eksperimen yang menggunakan

pembelajaran kooperatif dan kelas $\mathrm{C}$ sebagai kelas kontrol yang menggunakan metode presentasi diskusi. Instrumen yang digunakan dalam penelitian ini meliputi tes dan angket.

Data hasil penelitian yang diperoleh berupa data kuantitatif yaitu hasil tes prates, pascates dan hasil angket. Data yang berupa hasil tes pratest dan pascates mahasiswa dianalisis dengan teknik:

1. Menghitung nilai prates dan pascates sesuai dengan skala penilaian yang telah ditetapkan.

2. Menganalisis data nilai pratest dan pacsates secara statistik menggunakan program Statistical Product and Service Solution (SPSS). Adapun teknik analisis yang digunakan adalah uji normalitas, dan uji hipotesis.

\section{Hasil Penelitian}

\section{Efektifitas Pemahaman Konsep Mahasiswa dengan Menggunakan Model Pembelajaran Koopreatif}

Efektifitas pemahaman konsep mahasiswa dianalisis melalui hasil prates dan pascates. Namun sebelumnya data-data tersebut diuji normalitasnya dan kemudian dilanjutkan dengan analisis data Wilxocon untuk mengetahui adanya

\section{PEMBAHASAN}

perbedaan peningkatan pemahaman konsep mahasiswa yang pembelajarannya menggunakan model pembelajaran kooperatif.

Dari hasil perhitungan diperoleh harga $Z=-5,185$. Dengan memperhatikan harga asymp.sig untuk uji dua sisi adalah 0,00 yang lebih kecil dari harga alpha 0,05. Maka $\mathrm{H}_{0}$ dapat diterima. Dengan demikian dapat ditarik kesimpulan terdapat perbedan 
dalam mengajar dengan menggunakan kooperatif.

2. Efektifitas Pemahaman Konsep Mahasiswa dengan Menggunakan Metode Presentasi Diskusi.

Dari hasil perhitungan menggunakan analisis data Wilxocon diperoleh harga $Z=-3,329$. Dengan memperhatikan harga asymp.sig untuk uji dua sisi adalah 0,01 yang lebih kecil dari harga alpha 0,05. Maka $\mathrm{H}_{0}$ dapat diterima. Dengan demikian dapat ditarik kesimpulan terdapat perbedaan dalam mengajar dengan menggunakan metode presentasi diskusi.

\section{Perbedaan Hasil Pemahaman Konsep Mahasiswa antara Penggunaan Model Pembelajaran Kooperatif dengan Metode Presentasi Diskusi}

Untuk mengetahui perbedaan hasil pemahaman konsep mahasiswa antara penggunaan model pembelajaran kooperatif dengan metode presentasi diskusi maka pengujian dilakukan dengan uji $-t$ Mann-Whitney untuk dua sample yang independen. Pertama menguji signifikansi perbedaan rerata pada prates. Uji beda rata-rata terhadap prates pemahaman konsep antara model kooperatif dan metode presentasi diskusi diperoleh harga $\mathrm{U}=$ 479 , yang merupakan jumlah rangking terkecil.dan pada taraf signifikansi 0,05 diperoleh $p$ (sig.(2-tailed) $=0,11$. Itu artinya nilai signifikansi yang diperoleh dari hasil perhitungan lebih besar dari taraf signifikansi $\alpha=0,05$. $0,11>0,05$. Maka hipotesis nol diterima yang menyatakan tidak terdapat perbedaan rerata skor prates pemahaman mahasiswa sebelum menggunakan model pembelajaran kooperatif dan metode presentasi diskusi.

Selanjutnya untuk mengetahui perbedaan hasil pemahaman konsep mahasiswa antara penggunaan model pembelajaran kooperatif dengan metode presentasi diskusi pada pascates maka pengujian dilakukan dengan uji-t Mann-Whitney untuk dua sample yang independen. Hasil perhitungan uji beda rata-rata terhadap pascates pemahaman konsep antara model kooperatif dan metode presentasi diskusi pada taraf signifikansi 0,05 diperoleh $p$ (sig.(2tailed) $=0,00$. Itu artinya nilai signifikansi yang diperoleh dari hasil perhitungan lebih kecil dari taraf signifikansi $\alpha=0,05.0,00<0,05$. Maka $\mathrm{H}_{0}$ tidak dapat diterima dan $\mathrm{H}_{1}$ diterima. Dengan melihat hasil data tersebut dapat ditarik kesimpulan ada perbedaan antara model pembelajaran Kooperatif dengan metode presentasi diskusi.

Untuk mengetahui perbedaan ratarata antara dua kelas pada prates dan pascates. Hasil perhitungan selengkapnya dapat dilihat pada tabel 1.

Tabel 1 Hasil Rata-rata

\begin{tabular}{|l|c|c|}
\hline & Kooperatif & $\begin{array}{c}\text { Presentasi } \\
\text { Diskusi }\end{array}$ \\
\hline $\begin{array}{l}\text { Rata - rata } \\
\text { Prates }\end{array}$ & 52,43 & 48,57 \\
\hline $\begin{array}{l}\text { Rata - rata } \\
\text { Pascates }\end{array}$ & 69,00 & 53,86 \\
\hline $\begin{array}{l}\text { Kenaikan } \\
\text { Rata-rata }\end{array}$ & 16,57 & 5,29 \\
\hline $\begin{array}{l}\text { Presentase } \\
\text { Kenaikan } \\
\text { Rata-rata }\end{array}$ & $\mathbf{3 2} \%$ & $\mathbf{1 1 \%}$ \\
\hline
\end{tabular}

Berdasarkan tabel diatas kelas yang menggunakan model pembelajaran kooperatif menunjukan peningkatan lebih besar daripada kelas yang 
menggunakan metode presentasi diskusi. Kenaikan rata-rata kelas yang menggunakan kooperatif 16,57 atau $32 \%$. Sedangkan kelas yang menggunakan metode presentasi diskusi 5,29 atau $11 \%$. Untuk melihat hasil perbedaan antara kedua kelompok dalam bentuk gambar 1 .

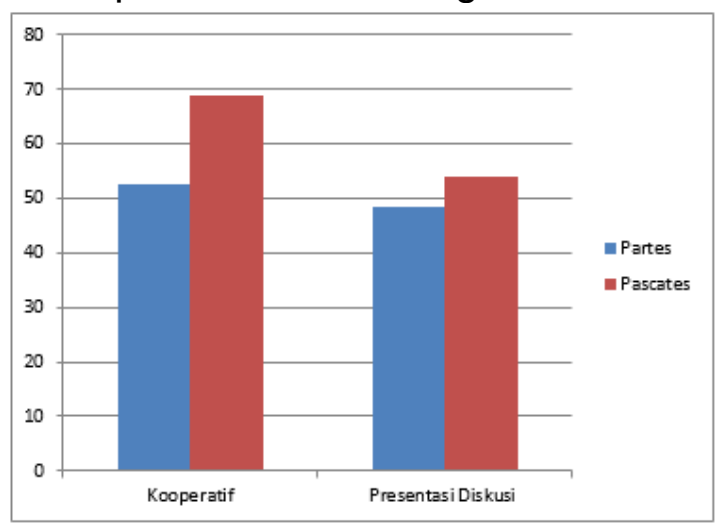

Gambar 1. Perbedaan Hasil Pemahaman Konsep

\section{Hasil Respon Mahasiswa terhadap Model Pembelajaran Kooperatif dan Presentasi Diskusi Mata Kuliah Pendidikan IPS Jurusan PGSD FKIP UNIKU}

Hasil analisis data terhadap 70 mahasiswa kelas eksperimen dan kelas kontrol mengenai tanggapan penggunakan metode oleh dosen menunjukan bahwa $97 \%$ mayoritas menyatakan setuju bahwa metode pembelajaran kooperatif lebih efektif digunakan untuk belajar matakuliah pendidikan IPS SD. Sementara dikelas kontrol yang menggunakan metode presentasi diskusi hanya 66 $\%$ menyatakan setuju bahwa metode presentasi diskusi effektif. Dari data tersebut dapat disimpulkan bahwa pembelajaran kooperatif lebih effektif dibandingkan dengan metode presentasi diskusi untuk digunakan dalam matakuliah pendidikan IPS SD. Tanggapan mahasiswa mengenai daya tarik pembelajaran dari kedua metode pembelajaran yang digunakan dosen adalah sebagai berikut: $61 \%$ menyatakan setuju bahwa metode presentasi diskusi membuat mahasiswa merasa jenuh atau membosankan, $50 \%$ menyatakan bahwa metode presentasi diskusi membuat mahasiswa tertekan, $70 \%$ mahasiswa menyatakan metode presentasi diskusi membuat mereka menagntuk, $40 \%$ merasa rugi belajar dengan metode presentasi, akan tetapi sebaliknya $89 \%$ menyatakan setuju bahwa pembelajaran kooperatif membuat pelajaran pendidikan IPS lebih menarik untuk dipelajari sementara metode presentasi $63 \%$. Dari hasil tanggapan mahasiswa tersebut dapat disimpulkan bahwa daya tarik pembelajaran kooperatif lebih menarik dibandingkan metode presentasi untuk digunakan dalam matakuliah pendidikan IPS SD.

Pengaruh metode terhadap keterampilan mahasiswa menunjukan bahwa $86 \%$ menyatakan setuju bahwa pembelajaran kooperatif dapat membuat mahasiswa lebih terampil sedangkan dengan menggunkan metode presentasi diskusi $75 \%$.

Sementara tanggapan mahasiswa mengenai pemahaman materi pada matakuliah pendidikan IPS SD bisa dilihat perbandingannya sebagai berikut: $60 \%$ menyatakan bahwa mahasiswa merasa kurang memahami materi dengan menggunakan metode presentasi diskusi. Namun sebaliknya, $85 \%$ mahasiswa menyatakan lebih memahami materi dengan menggunakan pembelajaran kooperatif. Dan $88 \%$ menyatakan bahwa materi lebih mudah diingat dengan menggunakan pembelajaran kooperatif. Dari data tersebut menunjukan bahwa pemahaman materi mahasiswa lebih baik dengan 
menggunakan

kooperatif.

Pengaruh metode pada motivasi mahasiswa dalam matakuliah pendidikan IPS dari data diatas menunjukan bahwa $90 \%$ mayoritas setuju bahwa dengan pembelajaran kooperatif dapat meningkatkan motivasi belajar mereka, sementara pada metode presentasi diskusi hanya $67 \%$ mahasiswa yang menyatakan setuju.

Tanggapan mahasiswa mengenai keaktifan dikelas dalam penggunaan metode yang dilakukan oleh dosen menunjukan bahwa sebanyak $42 \%$ mahasiswa berpendapat mereka tidak dapat mengemukakan pendapat saat belajar pendidikan IPS menggunakan metode presentasi diskusi. Sementara dengan menggunakan pembelajaran kooperatif $89 \%$ mayoritas mahasiswa setuju metode tersebut bisa melatih untuk bisa mengemukakan pendapat. Data tersebut dikuatkan dengan 88 $\%$ menyatakan setuju bahwa pembelajaran kooperatif bisa membuat mahasiswa menjadi lebih aktif. Dan dengan metode presentasi diskusi $69 \%$. Dari data tersebut dapat disimpulkan pembelajaran kooperatif dapat membuat mahasiwa lebih aktif dikelas dan bisa melatih mereka dalam mengemukakan pendapat.

\section{Pembahasan}

1. Perbedaan Pemahaman Konsep Mahasiswa antara Penggunaan Model Pembelajaran Kooperatif dengan Metode Presentasi Diskusi

Hasil penelitian ini menunjukan bahwa hipotesis $\left(\mathrm{H}_{0}\right)$ ditolak dan diterimanya $\left(\mathrm{H}_{1}\right)$. Terdapat perbedaan hasil antara mahasiswa yang belajar menggunakan model pembelajaran kooperatif dengan metode presentasi diskusi terhadap pemahaman konsep mahasiswa. Itu artinya, model pembeajaran kooperatif lebih efektif dalam pembelajaran matakuliah pendidikan IPS SD. Hal ini sejalan dengan pendapat Johnson (Tritanto, 2011:57) yang menyatakan bahwa tujuan pokok belajar kooperatif adalah memaksimalkan belajar siswa untuk meningkatkan prestasi akademik dan pemahaman baik secara individu maupun kelompok. Para ahli telah menunjukan bahwa pembelajaran kooperatif dapat meningkatkan kinerja siswa dalam tugas-tugas akademik, unggul dalam membantu siswa memahami konsep-konsep yang sulit, dan membantu siswa menumbuhkan kemampuan berpikir kritis. Pembelajaran kooperatif dapat memberikan keuntungan baik pada siswa kelompok bawah maupun kelompok atas yang bekerja bersama menyelesaikan tugas-tugas akademik. Jika ditinjau secara statistik perbedaan peningkatan antara kelas yang menggunakan model pembelajaran kooperatif dan kelas yang menggunakan presentasi diskusi adalah sebagai berikut: rata-rata prates kelas kooperatif yaitu 52,43 dan pada saat pascates rata-ratanya 69,00 . Kenaikan peningkatanya sebesar 16,57. Sedangkan untuk kelas presentasi diskusi, pada saat prates rata-ratanya 48,57 dan pada saat pascates ata-ratanya 53,86 . Kenaikan peningkatannya sebesar 5 ,29. Jika dilihat dari kedua hasil penggunaan metode tersebut maka dapat disimpulkan bahwa peningkatan kelas yang menggunakan kooperatif lebih besar dibandingkan dengan kelas presentasi diskusi.

Permasalahan dalam penelitian ini adalah dosen membutuhkan waktu yang cukup lama untuk menerapkan model pembelajaran kooperatif sementara waktu yang tersedia tidak mencukupi. Dosen harus lebih 
mempersiapkan materi dan teknik pembelajaran setiap kali pertemuan. Hal ini berbeda dengan kelas yang menggunakan presentasi diskusi, mahasiswa sudah siap untuk menampilkan dan membahas materi untuk didiskusikan dengan rekanrekannya dikelas. Dosen hanya menyiapkan materi tambahan dan meluruskan diskusi dari mahasiswa.

\section{Respon Mahasiswa terhadap Model Pembelajaran Kooperatif dan Presentasi Diskusi Matakuliah Pendidikan IPS SD Jurusan PGSD FKIP UNIKU}

Respon mahasiwa terhadap model pembelajaran kooperatif dan presentasi diskusi pada matakuliah pendidikan IPS SD di jurusan PGSD FKIP UNIKU secara keseluruhan menunjukan mereka lebih menyukai pembelajaran dengan kooperatif. Hal ini ditunjukan dari hasil angket yang dbagikan kepada mahasiswa baik dikelas yang menggunakan kooperatif maupun kelas yang menggunakan presentasi diskusi. Hasil persentase efektifitas penggunaan model kooperatif $97 \%$ sedangkan dengan penggunaan metode presentasi diskusi $66 \%$. Dari data tersebut dapat disimpulkan bahwa pembelajaran kooperatif lebih effektif dibandingkan dengan metode presentasi diskusi untuk digunakan dalam matakuliah pendidikan IPS SD.

Tanggapan mahasiswa mengenai daya tarik pembelajaran dari kedua metode pembelajaran yang digunakan dosen adalah $89 \%$ menyatakan setuju bahwa pembelajaran kooperatif membuat pelajaran pendidikan IPS lebih menarik untuk dipelajari sementara metode presentasi diskusi $63 \%$. Dari hasil tanggapan mahasiswa tersebut dapat disimpulkan bahwa daya tarik pembelajaran kooperatif lebih menarik dibandingkan metode presentasi untuk digunakan dalam matakuliah pendidikan IPS SD.

Pengaruh metode terhadap keterampilan mahasiswa menunjukan bahwa $86 \%$ menyatakan setuju bahwa pembelajaran kooperatif dapat membuat mahasiswa lebih terampil sedangkan dengan menggunkan metode presentasi diskusi $75 \%$.

Sementara tanggapan mahasiswa mengenai pemahaman materi pada matakuliah pendidikan IPS SD bias dilihat perbandingannya sebagai berikut: $60 \%$ menyatakan bahwa mahasiswa merasa kurang memahami materi dengan menggunakan metode presentasi diskusi. Namun sebaliknya, $85 \%$ mahasiswa menyatakan lebih memahami materi dengan menggunakan pembelajaran kooperatif. Dari data tersebut menunjukan bahwa pemahaman materi mahasiswa lebih baik dengan menggunakan pembelajaran kooperatif.

Pengaruh metode pada motivasi mahasiswa dalam matakuliah pendidikan IPS dari data diatas menunjukan bahwa $90 \%$ mayoritas setuju bahwa dengan pembelajaran kooperatif dapat meningkatkan motivasi belajar mereka, sementara pada metode presentasi diskusi hanya $67 \%$ mahasiswa yang menyatakan setuju.

Tanggapan mahasiswa mengenai keaktifan dikelas dalam penggunaan metode yang dilakukan oleh dosen menunjukan bahwa sebanyak $42 \%$ mahasiswa berpendapat mereka tidak dapat mengemukakan pendapat saat belajar pendidikan IPS menggunakan metode presentasi diskusi. Sementara dengan menggunakan pembelajaran kooperatif $89 \%$ mayoritas mahasiswa setuju metode tersebut bisa melatih 
untuk bisa mengemukakan pendapat. Data tersebut dikuatkan dengan 88 $\%$ menyatakan setuju bahwa pembelajaran kooperatif bisa membuat mahasiswa menjadi lebih aktif. Dan dengan metode presentasi diskusi $69 \%$. Dari data tersebut dapat disimpulkan pembelajaran kooperatif dapat membuat mahasiwa lebih aktif dikelas dan bisa melatih mereka dalam mengemukakan pendapat.
Namun dalam proses pembelajarannya tentu masih mengalami hambatan-hambatan. Hambatan pertama mahasiswa kurang serius dalam pembelajaran, kelas menjadi gaduh, banyak mengobrol dengan teman, dan kurang cukupnya waktu untuk memberikan evaluasi pembelajaran.

\section{SIMPULAN}

Sejalan dengan rumusan masalah penelitian, dan berdasarkan penelitian yang berkenaan dengan hasil studi empirik tentang pengaruh model pembelajaran kooperatif vs presentasi diskusi terhadap pemahaman konsep (keefektifan dan daya tarik pembelajaran) mahasiswa pada matakuliah pendidikan IPS di jurusan PGSD FKIP UNIKU. Maka hasil penelitian yang telah diperoleh dapat disimpulkan:

Pertama, pengaruh pembelajaran kooperatif dapat model meningkatkan pemahaman konsep mahasiswa pada matakuliah pendidikan IPS SD. Peningkatan pemahaman konsep ini dibuktikan dengan hasil $\mathrm{N}_{\text {gain }}$ pada prates dan pascates sebesar 0,35 . Peningakatan tersebut dapat disimpulkan bahwa pembelajaran dengan menggunakan pembelajaran kooperatif mengalami peningkatan dalam kategori sedang.

Kedua, pengaruh metode presentasi diskusi juga terdapat perbedaaan hasil pemahaman konsep mahasiswa pada matakuliah pendidikan IPS SD. Peningkatan pemahaman konsep ini dibuktikan dengan hasil $\mathrm{N}_{\text {gain }}$ pada prates dan pascates sebesar 0,10 . Peningakatan tersebut dapat disimpulkan bahwa pembelajaran dengan menggunakan metode presentasi diskusi mengalami peningkatan dalam kategori rendah.

Ketiga, perbedaan hasil pemahaman konsep mahasiswa antara penggunaan model pembelajaran kooperatif dengan metode presentasi diskusi pada saat prates menunjukan tidak terdapat perbedaan rerata skor prates pemahaman mahasiswa sebelum menggunakan model pembelajaran kooperatif dan metode presentasi diskusi. Sedangkan pada saat pascates terdapat perbedaan hasil pemahaman konsep mahasiswa antara yang menggunakan model pembelajaran Kooperatif dengan yang menggunakan metode presentasi diskusi. Perbedaan peningkatan antara kelas yang menggunakan kooperatif dan kelas yang menggunakan presentasi diskusi adalah 11,28 atau $21 \%$. Oleh karena itu dapat disimpulkan kelas yang menggunakan kooperatif lebih dapat meningkatkan pemahaman mahasiswa dalam matakuliah pendididkan IPS SD.

Dan terakhir, respon mahasiswa terhadap model pembelajaran kooperatif dan presentasi diskusi pada matakuliah pendidikan IPS SD di jurusan PGSD FKIP UNIKU secara keseluruhan menunjukan mereka 
lebih menyukai pembelajaran dengan metode presentasi diskusi. kooperatif dibandingkan dengan

\section{DAFTAR PUSTAKA}

Badan Standar Nasional Pendididkan. (2006). Model Penilaian Kelas. Jakarta: BSNP.

Deutsch, M. (1962). Cooperation and Trust: Some Theoretical Notes. In M. R. Jones (Ed.), Nebraska symposium on motivation (pp. 275-319). Lincoln, NE: University of Nebraska Press.

Hamalik, Oemar. (2009). Proses Belajar Mengajar. Bandung. Bumi Aksara.

Joyce \& Weil. (2009). Model of Teaching. USA: Allyn \& Bacon.

Nana Sudjana. (2005). Penilaian Hasil Proses Belajar Mengajar. Bandung: PT Remaja Rosdakarya.

Nurdin, Somantri. (2005). Metode Presentasi Dengan Ms Power Point Untuk Mengembangkan
Kemampuan Writing Dan Speaking. Artikel. Pendidikan Network. $\quad$ http://researchengines.com/0305soma ntri2.html

Rahman, Fazalur. (2011). Impact of Discussion Method on Students Performance. International Journal of Business and Social Science Vol. 2 No. 7; [Special Issue -April 2011].

Slavin, R E. (1995). Cooperative learning theory, research, and practice. USA: Allyn \& Bacon.

Susanto, Ahmad. (2014). Pengembangan Pembelajaran IPS di Sekolah Dasar. Jakarta: Prenadamedia Group.

Tritanto. (2011). Mendesain Model Pembelajaran Inovatif-Progresif. Jakarta: Kencana Perdana Media Group 